\title{
Western Presence in Emerging Markets: A Content Analysis of Western Presence in South African Television Commercials
}

\author{
Yuvay Jeanine Meyers (Corresponding author) \\ School of Business, Howard University \\ $26006^{\text {th }}$ Street NW, Washington, DC, USA \\ Tel: 1-202-806-1554 E-mail: ymeyers@howard.edu \\ Ephraim Okoro \\ School of Business, Howard University \\ $26006^{\text {th }}$ Street NW, Washington, DC, USA \\ Tel: 1-202-806-1545 E-mail: eaokoro@howard.edu
}

Received: January 3, 2012 Accepted: January 19, 2012 Published: April 1, 2012

doi:10.5539/ijms.v4n2p67 URL: http://dx.doi.org/10.5539/ijms.v4n2p67

\begin{abstract}
There is major growth opportunity for businesses entering emerging markets. Advertising to consumers within these markets is an issue that marketing strategists must examine in order to prepare for success. In this content analysis of an emerging market's (South Africa) primetime television, a snapshot of the local advertising landscape is examined in order to identify the current level of western investment. This study seeks to provide insight on the languages spoken, the ethnicity of the actor, and the products marketed in these advertisements to have an idea about the strategies being employed by western companies to communicate in this emerging market.
\end{abstract}

Keywords: Emerging markets, Advertising, Content analysis, South Africa

\section{Introduction}

Business has shown an increasing interest in the world's emerging markets, which is fueled by "the relatively high returns recorded by emerging markets and by their perceived potential for large returns in the future" (Porter 1993). Emerging markets are where the most growth potential lies in today's marketplace (Arnold and Quelch 1998). Characterized as being highly volatile, emerging markets also have the potential to provide higher than average returns, making it attractive to global business (Barry and Lockwood, 1995; Mwenda, 2000; Kehl, 2007). With these emerging markets now making up almost $80 \%$ of the world's consumers (Steenkamp\& Burgess, 2002), understanding communication with these consumers is one of the most valuable areas for companies to undertake in order to capitalize on this opportunity. South Africa is of particular interest for business investors because it is the only Sub-Saharan country in Africa that is internationally recognized as an emerging market (Kehl 2007). With a population of about 50 million people and a Gross Domestic Product of $\$ 500$ Billion (South African Census 2011), the potential for returns in the relatively untapped African market makes this country a prime target for investment.

Several recent studies have examined the increasing interests of global and multinational firms in sub-Saharan Africa, specifically South Africa. Some of the authors expressed divergent views in terms of short- and long-term objectives of international businesses in the country (Bloom \&Reene, 2006; Escribano\&Guasch, 2005). Others were consistent in their positions regarding investment opportunities, overall incentives, and strategic intent of South Africa's global business partners (Taylor, 2009; World Bank, 2006). Increasingly, research findings indicate that some multinational corporations and investors lack adequate knowledge of the challenges and issues associated with business and entrepreneurial climate in sub-Saharan Africa (World Bank, 2006; Taylor, 2009). As the trend of globalization intensifies and corporations are exploring emerging markets, lack of knowledge about the business climate and frustrations resulting from the challenges involved in dealing with cultural and economic situations in the country may be causing the reluctance to invest in these countries. Indeed, South Africa is no 
exception to this investment situation as the business environment and investment opportunities in the country call for political, cultural, and economic understanding and adjustment. In spite of these challenges, there are Western companies that are successfully conducting business in South Africa (Kehl 2007). The question that is then posed by this study is how visibly present or invested are these companies in marketing communications in this country and what are the attributes use during this communication.

Holsti (1969) defines content analysis as "any technique for making inferences by objectively and systematically identifying specified characteristics of messages." In this content analysis of South African primetime television, the goal is to identify the level of western investment in that country by counting the frequency of advertising that markets western originated products, goods, and services. This study seeks to provide insight on the languages spoken, the ethnicity of the actor, and the product marketed in these advertisements to have an idea about the strategies being employed by western companies to communicate in this emerging market. With advertising being a predominant way that firms entering a foreign market compete and build a reputation (Rindova, Petkova, and Kotha 2007), its anticipated that the findings of this study will provide a snapshot of the current marketing communications effort by western businesses entering the marketplace in South Africa with hopes of succeeding. In this portrayal, we will also have a chance to see which competing view on foreign advertising strategies has been used in this context when a western company advertises in this market.

South Africa is often cited as one of the world's premier upcoming markets, however, very few academic studies have been conducted that examine Western presence in this emerging market. With a goal of measuring this presence through advertising visibility, this paper aims to add to the business literature an example that has yet to be examined. This manuscript has three main components. The first section presents literature that supports the significance of western companies expanding business and marketing in emerging markets. Second, the paper presents the research findings from a content analysis of current western presence in one of the world's most promising emerging market, South Africa. The third and final section discusses the research findings and identifies direction for future research.

\section{Background}

In today's marketplace, companies are turning towards newly emerging markets for growth in order to combat over saturation of the world's more developed markets (Swami and Dutta 2010). With the development of previously less prominent markets, the number of consumers in the world's middle income households increases (Manrai and Manrai 2001). Consumers in these emerging markets represent an increasing number of prospective sales and therefore are attractive to companies as a source of potential business expansion. The big emerging markets of the world, including the countries of Argentina, China, India, Mexico, Poland, South Africa, and Turkey, are reporting a rising trend of consumer disposable income growth (Big Emerging Markets 1994). Competition is becoming fierce as marketers from companies in the more developed markets fight to reach these new middle income consumers. Ad spend by Western companies aggressively trying to enter emerging markets can be upwards of $50 \%$ of total expenditures in the market. Understanding how to effectively reach this new audience through advertising strategy may be the key to success in these emerging markets along with providing justification for the ad dollars spent.

Research regarding international marketing has not reached a consensus on whether globally standard or local adaptation advertising is the best method for companies investing in emerging economies (Fastoso 2010). It is however it is commonly accepted that having a global branding strategy and standardized advertising, tends to be synonymous with prestige (Meyer and Tran 2006). There are also benefits to presenting localized advertisements when entering an emerging market. By appearing to be local, the brand is seen as less invasive and more personalized. Western companies entering an emerging market must decide how they want to be perceived (global or local) and whether the level of invasiveness chosen will net the greatest gain. Since, it is currently unclear which method is preferred by multinational companies that chose to enter these markets, this study will examine a sample country and account for the percentage of overtly western (globally standard) advertisements seen during a specified period.

There are competing schools of thought regarding what should be portrayed in advertisements and how they should compare to the society where they are seen. One accepted theory argues that advertising should mirror society (Brown 1981; Peterson 1983; Belk and Pollay 1985) and foreign companies should therefore localize their advertisements. In line with this, utilizing proportionality as a criterion, representation should be comparative to what is seen in the larger population (Faber, O'Guinn, \& Meyer, 1987).Using this study as an example, with about $79.5 \%$ of the South African population being racially Black (South African Government, 2011), according to this standard, the overwhelming majority of the people portrayed in this study should also be 
Black. Again following this school of thought, English should be the predominant language used by western advertisements in South Africa because it is the most common language spoken in public. In summation of this line of thought, the people in the society should look like the images portrayed, the frequency of racial demographic should be equivalent to that of the society, and the language used should correspond to the language used in the country.

The other line of accepted theory states that remaining true to country of origin standards should prevail when western companies advertise in a foreign market (Buzell, 1968; Fatt, 1967; Killough, 1978; Levitt, 1983; Sorenson and Weichmann, 1975). There is a notion that westerners possess sophisticated tastes or preferences (Cohen 1992) and by virtue of association, western products should be displayed as obviously western to capitalize on this positive affect. Also, by using an ad with an endorser of the same ethnicity as the audience may fail to create a global or country-of-origin-consistent brand identity if that is desired (Ryu, Park, and Feick 2006). Proponents of this thought also feel that the same ad used in the country of origin is sufficient to be used in the market they are entering. Accordingly, standardization is the preferable strategic approach because all consumers have similar needs and wants that can be appealed to through the same streamlined advertisement that works in the country of origin. If the western companies currently advertising in South Africa take this line of thought, most of the ads for western products will feature western models.

With these competing theories, there is a need for research in emerging markets both to advance marketing as an academic discipline and also to maintain its current managerial relevance. South Africa is an ideal setting for a study examining advertising in emerging markets due to its commonality in characteristics that help to classify emerging markets such as having "a multicultural society increasing in diversity through immigration and urbanization, an increasing buying power among traditionally economically disadvantaged groups, and a market where politics are as central as economics" (Jain, 2006; Johnson, Elliot and Grier 2010). Using South Africa as the sample, this study seeks to provide insight on the languages spoken, the ethnicity of the actor, and the product marketed in these advertisements to have an idea about the strategies being employed by western companies to communicate in this emerging market. The following questions will be addressed by this research:

1) With what frequency are Western companies advertising in South African media?

2) What language is primarily used by these Western advertisers?

3) What ethnicity are the actors in these advertisements?

4) What products are being advertised by these Western companies?

\section{Methodology}

Content Analysis has been defined as "a research technique for the objective, systematic, and quantitative description of manifest content of communications" (Berelson, 1952). This methodology, used often when examining media, can quantify the presence of an object or theme to provide an in depth understanding of the communication. In order to get a snapshot of current television advertisement in South Africa, this research focused on that country's main public television station, SABC 1. Also known as, MzansiFoSho, SABC 1 is South Africa's biggest TV brand with over 23.6 million adult viewers, and a $74 \%$ penetration of the adult population (SABC Annual Report 2010). Programming on this channel is comprised of local, national, and international content. In terms of western presence in South African television media, this would be the location of the logical vehicle choice.

A one week (7 days) sample of primetime television between the hours of $18 \mathrm{~h} 00$ and $22 \mathrm{~h} 00$ (6-10 pm) was recorded in October of 2009. All of the advertisements were coded and yielded 408 sample ads. In order to allow for generalizations, a simple random sample was taken and $95 \%$ confidence is provided by the measurements (Neuendorf 2002). The questions on the code sheet were developed to address the overarching goal of this study. Additional questions were also posed on the code sheet in order to see if there are any identifiable relationships between western company presence in the advertisements and the ethnicity of the actors, the products being advertised, and or the language spoken by the actors.

\subsection{Inter-coder Reliability}

The coding of this study was conducted by two graduate students in the business school at a private university in the United States of America. Both of the students who served as coders are students with extensive experience in research methods and advertisements. They are also both ethnically Black, which arms them a unique perspective of the advertisements. Using the method developed by Perreault and Leigh (1989), the coding of the two coders were compared to determine inter-coder reliability. According to this method, acceptable reliability calls for coefficients over 0.80 . This study thus meets the minimum standard of reliability with all of the 
variables equaling over 0.84 . The overall reliability of the study was 0.93 .

\subsection{Variables}

In order to classify the country of origin for the brand advertised on the commercials analyzed, cultural context cues were used to associate the labels "Western" versus "Local". The coders looked for identifiers such explicit declarations of brand nationality, individual knowledge of brand origin (examples: Coca-Cola/USA, Unilever/Anglo-Dutch), and culturally identifying icons such as the Eiffel Tower (France) and the American flag (USA). The product categories of the featured brands were coded in the study as well.

The ethnicity of the main actor was another important variable in this study. Ethnicity was coded as Black, White, Other, or Cannot Discern. The coders used western oriented categories based purely on skin tone and facial features. Thus being the case, both Black Africans and Coloureds (in South African ethnic stratification) would have been coded as Black. The languages spoken by the main actor also helped to give valuable information about this study. According to the official South African government website (2011), the country has 11 official languages: English, isiZulu, isiXhosa, isiNdebele, Afrikaans, siSwati, Sesotho sa Leboa, Sesotho, Setswana, Tshivenda, and Xitsonga. Of these languages, English is the most widely understood since it is the language used in the education system. For example, most educational materials used in South Africa are in either Afrikaans or English (Setati et al 2002). The coders were not familiar with the official languages outside of English and thus coded for English and categorized the other spoken languages as "Other".

\section{Results}

To analyze the data collected, SPSS was used to take count of the products advertised on the television station based upon the company's origin (Western versus Non-Western) and cross-tabulations were done between the origin and other attributes of the ad such as language spoken, product category, and ethnicity of the main actor. These results will allow the research to address the questions posed.

Of the 408 commercials coded, 122 were classified as being commercials for western (US or European) brands $(\mathrm{n}=122,29.9 \%)$. Most of the brands advertised on during the analysis, however, were seemingly local or South African in origin $(n=248,60.8 \%)$. The remaining portion was unidentifiable in terms of being Western or Local brands ( $\mathrm{n}=38,9.3 \%)$.

When examining the characteristics of the advertisements in relation to the perceived brand origin, some interesting facts were noted. Of the 408 commercials, only $1.5 \%(\mathrm{n}=6)$ were depicted in a language other than English. In commercials that featured Western brands, less than $1 \%(\mathrm{n}=1)$ featured a language other than English. This abnormality is discussed further in a preceding section. The local brands also overwhelmingly also typically featured English as the featured language $(n=245)$ with less than $1 \%(n=3)$ featuring another language. Although many of the ads analyzed didn't feature speaking models $(n=176,43.1 \%)$, those that did primarily featured Black actors in the leading role $(\mathrm{n}=144,35.3 \%)$. Only $15.4 \%$ of ads featured a White actor in the leading role $(\mathrm{n}=63)$.

Most of the commercials on SABC1 were classified as movie or television show promotional commercials $(\mathrm{n}=66,16.2 \%)$. Categories tied for second in quantity, were Telecommunication/Cell Phone advertisements $(\mathrm{n}=56,13.7 \%)$ and promotions for Beauty Aids, Cosmetics, Personal Products, Skin Care, Deodorants etc. $(\mathrm{n}=56,13.7 \%)$. Food, Candy, and Snacks was next in quantity comprising $13.2 \%$ of the ads analyzed $(\mathrm{n}=54)$. Interestingly, two categories showed significant difference between countries of origin. Telecommunication/Cell Phone advertisements were predominately reported as local companies $(n=40,71.4 \%)$ while advertisements for Beauty Aids, Cosmetics, Personal Products, Skin Care, Deodorants etc. were predominately reported as Western companies $(\mathrm{n}=38,67.9 \%)$.

\section{Discussion}

Returning to the research questions previously presented, this study served to provide insight into each of the areas of inquiry.

\section{Research Question 1: With what frequency are Western companies advertising in South African media?}

According to the findings from this study, there is not an overwhelming presence of Western brands on South African television commercials. Although significant at $40 \%$ of sampled ads, the presence of Western industry advertising is not out pacing seemingly local brands. There is a possibility that there are several Western brands that have chosen to take on a local façade. However, current marketing research suggests that a strategy announcing the brand's global presence might be more effective than a local strategy for company's entering an emerging market (Alden, Steenkamp, and Batra 1999). 


\section{Research Question 2: What language is primarily used by these Western advertisers?}

English is the primary language of education used in South Africa (Setati et al 2002) and, unsurprisingly, the main language presented on the South African television commercials. Only $1.2 \%(n=5)$ of the ads analyzed featured a language other than English. Of this group, only one $(n=1)$ of the overtly Western brands did not feature English as the spoken language. Interestingly, when reexamined, this ad was for Vaseline which is an Anglo-Dutch brand owned by the Unilevel Company. Afrikaans is the language spoken in that ad which is a Dutch based language. The connection between the local language used in the ad and the company origin is noteworthy and an interesting way integrating a global brand into a local market.

\section{Research Question 3: What ethnicity are the actors in these advertisements?}

According to this study, the main actors featured in the advertisements analyzed are predominately Black regardless of brand origin. In line with the country's racial composition, Blacks and Coloureds make up $87.9 \%$ $(\mathrm{n}=9410671)$ of the South African population (South African Census, 2001). There have been numerous studies that have focused on the frequency in portrayal of Blacks in American advertising in a country where Blacks make up only a minority of the total population (Taylor and Lee, 1995). However, in the case of a country in Sub-Saharan Africa where Black populations are the overwhelming majority, there are very few studies examining the frequency in portrayal on television commercials in that region. Consistent with the proportionality criterion, this study confirms that racial representation in advertising should and does equal its proportion of the population (Faber, O'Guinn, and Meyer, 1987).

\section{Research Question 4: What products are being advertised by these Western companies?}

Of the products advertised in the sample commercial, there was a pronounced Western presence in the categories of health and beauty products, restaurants, food/beverage items, and children's toys and clothes ( $n=53,43.4 \%$ of items promoted). These categories are all considered luxury items due to their relation to beauty, comfort and refinement (Berry 1994). There is, thus, seemingly a value associated with Western luxury for South Africans. If the potential consumers are aware of the beauty ideals and social value that is associated with the brand internationally, that helps to qualify why these brands are promoted as Western.

\section{Conclusion}

The preceding results provided a defined account of the current landscape of advertising in South Africa. There is theoretical support stating that South Africa is one of the premier emerging markets on the continent of Africa and that Western investment should be highly prevalent here (Kehl 2007). However, in our study focusing on this market, less than $30 \%$ of the advertisements coded were of observable western origin. If the absence of more western presence in the sampled ads is a result of the absence of western companies in the South African marketplace, then companies are missing a valuable opportunity to invest in this emerging market. Nonetheless, if the advertisers were predominantly taking the localization approach, this would account for the majority of the advertisements being "local". Also in line with localization, of the ads examined, 98.5\% featured English as the spoken language and $86.4 \%$ of the human actors displayed were ethnically Black, regardless of whether it was an obviously western (standardized) or domestic ad. Standardization, or use of western advertisements directly from the country of origin, did not appear to be a widely used strategy.

One limitation of this study is the fact that the coders of the analysis were looking from a Western view point at the advertisements. The findings from this study do, however, provide valuable insight for Western companies hoping to enter the market. Unfortunately, the findings do not give insight into the perceived Western presence by the citizens of the emerging market. As with all content analysis research, this methodology does not give answers and reasons as to why the strategy used was implemented. It is simply a snapshot of what is currently present in the sample market. This truth does, however, provide another opportunity for future research to discover the qualitative and quantitative answers to the questions that surround this situation.

As Western businesses seek to grow in this increasingly competitive landscape, businesses must be open and aware of emerging markets in order to avoid stalling in an over saturated environment. Today's marketplace cannot simply be resigned to a domestic battleground. In order to compete, companies must both adapt within in their own market against increased competition from foreign entries to their market as well as expand their strategies to reach new potential consumers by targeting international markets (Johnson, Elliot, and Grier 2010). Although South Africa is often cited as one of the premier upcoming markets, very few studies have been conducted that examine advertising in emerging markets on the African continent. Through studies like this one, researchers can help to develop a record of best strategies in business situations that may impact the ultimate success of international ventures into a new market. 


\section{References}

Alden, D. L., Steenkamp, J. B., \& Batra, R. (1999). Brand positioning through advertising in Asia, North Americaand Europe: The role of global consumer culture. Journal of Marketing, 63(1), 75-87. http://dx.doi.org/10.2307/1252002

Arnold, David and John Quelch (1998). New strategies in emerging markets. Sloan Management Review, Vol. 40, Issue 1 (Fall 1998).

Barry CB., \& Lockwood LJ. (1995). New Directions in Research on Emerging Capital Markets. Financial Markets, Institutions and Instruments. Oxford: Blackwell Publishers.

Belk, R. W., \& Pollay, R. W. (1985). Images of Ourselves: The Good Life in Twentieth Century Advertising. Journal Of Consumer Research, 11(4), 887-897. http://dx.doi.org/10.1086/209024

Berelson, Bernard (1952). Content Analysis in Communication Research. Pp. 220. Glencoe, Ill.: The Free Press, 1952.

Berry, C. (1994). The idea of luxury. Cambridge: Cambridge University Press.

Big Emerging Markets. Business America, Special Issue 1994, pp. 59-65.

Bloom, N., \& Van Reene, J. (2006). Measuring and explaining management practices across firms and countries. Center for Economic Performance (CEP) discussionpaper No. 716.

Brown, Bruce W. (1981). Images of Eamily Life in Magazine Advertising: 1920-1978. New York: Praeger.

Buzzell, R. (1968). Can you standardize multinational marketing? Harvard Business Review, Vol. 46, November-December, pp. 102-19.

Cohen, J. (1992). White consumer response to Asian models in advertising. Journal of Consumer Marketing, 9, 17-27. http://dx.doi.org/10.1108/07363769210036999

Escribano, A., \& Guash, J. (2005). Assessing the impact of the investment climate onproductivity using firm-level data: Methodology and the cases of Guatemala, Honduras, and Nicaragua. Discussion paper WPS3621. Washington, D.C.: The World Bank.

Faber, R.J, O'Guinn, T.C., and Meyers, T.P. (1987). Televised Portrayals of Hispanics: A Comparison of Ethnic Perceptions. International Journal of Intercultural Relations, 11, 155-169. http://dx.doi.org/10.1016/0147-1767(87)90016-2

Fastoso, Fernando and Jeryl Whitelock (2010). Regionalization vs. globalization in advertising research: Insights from five decades of academic study. Journal of International Management, 16, pgs. 32-42. http://dx.doi.org/10.1016/j.intman.2009.02.005

Fatt, A.C. (1967). The danger of 'local' international advertising. Journal of Marketing, Vol. 31, No. 1, pp. 60-2.

Holsti, Ole (1969). Content Analysis for the Social Sciences and Humanities. Reading, MA: Addison-Wesley.

Jain, Subhash (2006). Emerging economies and the transformation of international business. Brazil, Russia, India and China (BRICs), Cheltenham, UK: Edward Elgar.

Johnson, Guillaume D., Elliott, Roger M., and Grier, Sonya A. (2010). Conceptualizing Multicultural Advertising Effects in the "New" South Africa. Journal of Global Marketing, 23: 3, 189 - 207. http://dx.doi.org/10.1080/08911762.2010.487420

Kehl, J.R. (2007). Emerging markets in Africa. African Journal of Political Science and International Relations, Vol. 1 (1), pp. 001-008, May 2007.

Killough, J. (1978). Improved payoffs from transnational advertising. Harvard Business Review, Vol. 56, July-August, pp. 102-10.

Levitt, T. (1983). The globalization of markets. Harvard Business Review, Vol. 61, May-June, pp. 92-102.

Manrai, Lalita A., and Ajay K. Manrai (2001). Marketing opportunities and challenges in emerging markets in the new millennium: a conceptual framework and analysis. International Business Review, 10 pgs. 493-504. http://dx.doi.org/10.1016/S0969-5931(01)00029-4

Meyer, Klaus E., \& Tran, Yen Thi Thu. (2006). Market Penetration and Acquisition Strategies for Emerging Economies. Long Range Planning, 39, no. 2, 177-197. http://dx.doi.org/10.1016/j.lrp.2006.04.004

Mwenda Kenneth (2000). Securities Regulation and Emerging Markets: Legal and Institutional Issues for 
Southern and Eastern Africa. Murdoch University Journal of Law and World Bank.

Neuendorf, Kimberly (2002). The Content Analysis Guidebook. Thousand Oaks, CA: Sage

Perreault, W. D., \& Leigh, L. E. (1989). Reliability of nominal data based on qualitative judgments. Journal of Marketing Research, 26 (May), 135-148. http://dx.doi.org/10.2307/3172601

Peterson, Robin T. (1983). Marketers Have a Social Obligation to Screen Out Negative Roles in Ads. Marketing News. (December 23), 2.

Porter Michael (1993). Closed-end Emerging Country Funds Review. In K.H. Park and W. Van Agtmael (eds), The World's Emerging Stock Markets. Chicago: Probus Publishers. p. 459.

Rindova, Violina P., Antoaneta P. Petkova and Suresh Kotha (2007). Standing Out: How New Firms in Emerging Markets Build Reputation. Strategic Organization, 5; 31. http://dx.doi.org/10.1177/1476127006074389

Ryu, G., Park, J., and Feick, L. (2006). The role of product type and country-of-origin in decisions about choice of endorser ethnicity in advertising. Psychology and Marketing, 23:487-513.

SABC Annual Report. (2010). [Online] Available: http://www.sabc.co.za/

Setati, Mamokgethi, Jill Adler, Yvonne Reed and AbdoolBapoo (2002). Incomplete Journeys: Code-switching and Other Language Practices in Mathematics, Science and English Language Classrooms in South Africa. Language And Education, Vol. 16, No. 2, 2002. http://dx.doi.org/10.1080/09500780208666824

Sorenson, R.Z., and Wiechmann, U.E. (1975). How multinationals view marketing standardization. Harvard Business Review, Vol. 53, May-June, p. 38.

South African Census. (2011). [Online] Available: http://www.statssa.gov.za/census01/html/RSAPrimary.pdf

South African Government Website. (2011). [Online] Available: http://www.info.gov.za/aboutsa/glance.htm

Steenkamp, Jan-Benedict and Burgess, Steven Michael (2002). Optimum Stimulation Level and Exploratory Consumer Behavior in an Emerging Consumer Market. International Journal of Research in Marketing, 19(2), 131-150. http://dx.doi.org/10.1016/S0167-8116(02)00063-0

Swami, Sanjeev and ArindamDutta (2010). Advertising strategies for new product diffusion in emerging markets: Propositions and analysis. European Journal of Operational Research, 204, pg. 648-661. http://dx.doi.org/10.1016/j.ejor.2009.11.009

Taylor, Charles R., and Ju Yung Lee (1995). Portrayals of African, Hispanic, and Asian Americans in Magazine Advertising. American Behavioral Scientist, 38 (4), 608-621. http://dx.doi.org/10.1177/0002764295038004010

Taylor, I. (2009). China's new role in Africa. Boulder, C.O.: Lynne Rienner Publishers

World Bank. (2006). World development indicators. Washington, D.C.: TheWorld Bank. 